Jurnal IImiah Iqra'

2541-2108 [Online] 1693-5705 [Print]

Tersedia online di: http://journal.iain-manado.ac.id/index.php/JII

\title{
Implementasi Kurikulum 2013 Revisi Sebagai Solusi Alternatif Pendidikan Di Indonesia Dalam Menghadapi Revolusi Industri
}

\section{0}

\author{
Gina Nurvina Darise \\ Fakultas Tarbiyah dan IImu Keguruan IAIN Manado \\ ginadarise@yahoo.co.id
}

\begin{abstract}
Abstrak
Disrupsi teknologi, khususnya teknologi informasi telah mewarnai revolusi industri 4.0 sehingga mendorong perubahan kebutuhan dan perkembangan masyarakat dalam bidang kehidupan, termasuk pendidikan. Hal ini merupakan salah satu pemicu perlunya dilakukan revisi terhadap kurikulum 2013 sebagai antisipasi perkembangan dan kebutuhan abad 21. Kurikulum 2013 Revisi merupakan wujud penyempurnaan kurikulum yang berbasis karakter sekaligus berbasis kompetensi. Dalam implementasinya,kurikulum 2013 Revisi menuntut guru untuk mengembangkan pembelajaran dengan mengintegrasikan empat hal penting, yaitu Penguatan Pendidikan Karakter (PPK), Literasi, Keterampilan Abad ke-21 (4C) dan Higher Order Thingking Skill (HOTS).
\end{abstract}

Kata kunci: $\quad$ Revolusi Industri 4.0; Kurikulum 2013

\begin{abstract}
Disruption of technology, especially information technology has colored the industrial revolution 4.0 so that it encourages changes in the needs and development of society in the field of life, including education. This is one of the triggers for the revision of the 2013 curriculum in anticipation of 21st century development and needs. 2013 Curriculum Revision is a form of perfecting a character-based and competency-based curriculum. In its implementation, the 2013 Revised curriculum requires teachers to develop learning by integrating four important things, namely Strengthening Character Education (SCE), Literacy, 21st Century Skills (4C) and Higher Order Thingking Skills (HOTS).

Keywords: The industrial revolution 4.0; 2013 Curriculum
\end{abstract}




\section{Pendahuluan}

Revolusi industri 4.0 berdampak domino pada semua sisi ruang kehidupan termasuk dunia pendidikan. Setelah masa kejayaan mesin, listrik dan teknologi informasi berbasis teknologi telah rampung, saatnya teknologi diturunkan menjadi instrument bagi seluruh komponen kehidupan. Turunan teknologi ini menjadi pemain penting dalam kehidupan manusia, bahkan cenderung mengontrol kehidupan manusia (Mubarak, 2018).

Tantangan masyarakat dan peserta didik dalam revolusi industri 4.0 adalah setiap anak manusia disentuh dan bersentuhan dengan teknologi sejak dia lahir bahkan sejak dalam kandungan. Misalnya, dalam era digital sekarang ini, ibu-ibu yang hamil merasa belum sempurna dan belum nyaman jika belum di USG (Ultrasonografi) dan alat yang digunakan untuk USG itu adalah produk teknologi. Hal itulah yang terjadi di alam revolusi indutri 4.0 sekarang ini. Oleh karena itu, tantangan masa depan dalam revolusi indutri 4.0 ini antara lain berkaitan dengan akselerasi teknologi dan sains, tren politik kekuatan ekonomi, tren social budaya modern, perubahan peta pengetahuan dan era post modern yang menuntut berbagai perubahan pendidikan. Menghadapi tantangan tersebut, pendidikan harus memperluas orientasi pada standar kompetensi pendidikan, agar berbagai perubahan dapat direalisasikan. Menyikapi hal tersebut maka sudah seharusnya setiap bidang kehidupan manusia perlu adanya penyesuaian manajemen pendidikan dalam berbagai level agar kita tidak terpuruk dalam era digital ini (Mulyasa, 2013).

Dalam Undang-Undang Sistem Pendidikan Nasional No. 20 Tahun 2003 disebutkan bahwa pendidikan adalah usaha sadar dan terencana untuk mewujudkan suasana belajar dan proses pembelajaran agar peserta didik secara aktif mengembangkan potensi dirinya untuk memiliki kekuatan spiritual keagamaan,pengendalian diri, kepribadian, kecerdasan, akhlak mulia, serta keterampilan yang diperlukan dirinya dan masyarakat (Tim Redaksi Sinar Grafika, 2007).

Dewasa ini berkembang suatu anggapan bahwa pendidikan bukan lagi merupakan suatu ilmu, melainkan suatu teknologi. Hal ini disebabkan oleh upaya pengembangan dan penyempurnaan pendidikan,khususnya kurikulum, lebih banyak datang dari pengalaman praktik di sekolah dibandingkan dengan dari penerapanpenerapan teori-teori yang sudah mapan. Perubahan atau penambahan isi 
kurikulum sering diadakan karena adanya kebutuhan-kebutuhan praktis (Sukmadinata \& Syaodih, 2017).

Pendidikan dipercaya sebagai alat strategis meningkatkan taraf hidup manusia. Melalui pendidikan manusia menjadi cerdas, memiliki skill, sikap hidup yang baik,sehingga dapat bergaul dengan baik pula di masyarakat dan dapat menolong dirinya sendiri, keluarga dan masyarakat. Pendidikan menjadi investasi yang memberi keuntungan sosial dan pribadi yang menjadikan bangsa bermartabat dan menjadikan individunya menjadi manusia yang memiliki derajat (Engkoswara \& Komariah, 2011).

Adapun hubungan dunia pendidikan dengan revolusi industri 4.0. adalah dunia pendidikan dituntut harus mengikuti perkembangan teknologi yang sedang berkembang pesat serta memanfaatkan teknologi informasi dan komunikasi sebagai fasilitas lebih dan serba canggih untuk memperlancar proses pembelajaran. Selain itu, diharapkan dengan pemanfaatan teknologi informasi dan komunikasi pola pikir pembelajaran dapat bergeser dari berpusat pada guru (teacher centered) menjadi berpusat pada peserta didik (student centered), metodologi yang semula lebih dominasi ekspositori berganti ke partisipatori dan pendekatan yang semula lebih banyak bersifat tekstual berubah menjadi kontekstual. Semua perubahan tersebut dimaksudkan untuk memperbaiki mutu pendidikan baik dari segi proses maupun hasil pendidikan (Trianto, 2007)

Untuk itu, Indonesia sebagai negara berkembang menuju negara maju haruslah memiliki kurikulum yang berfungsi menjadi kiblat proses pendidikan sehingga dapat mengantisipasi kebutuhan perkembangan abad 21, dan karakteristik peserta didik. Hal ini tentunya agar pendidikan di Indonesia dapat menyiapkan lulusan-lulusan berkualitas yang mampu bersaing, bersanding bahkan bertanding dalam era globalisasi.

\section{Kajian Teori}

\section{Revolusi Industri Dari Masa Ke Masa}

Istilah revolusi industri pertama kali dikemukakan oleh Arnold Toynbee tahun 1884. Hari ini kita mengenalnya sebagai Era Revolusi Industri 4.0, era ini hasil terjemahan The Fouth Industrial Revolution yang disingkat 4R. Sepanjang pengetahuan manusia, terutama manusia Eropa, awal kemajuan industri ditandai 
dengan ditemukannya mesin uap (steam). Kata kunci pada era 1IR adalah mesin uap. Era ini juga dikenal di Prancis atau di Inggris disebut Revolusi Industri. Saat itu pula perubahan manusia terkurung pada ruang terbatas. Mereka mulai menjelajah dunia dengan mesin uap yang dipasangkan di kapal laut mereka. Ketika mesin uap ditemukan maka kemajuan mereka dimulai. Mesin-mesin produksi digerakkan dengan uap, transport darat dibuat melalui kereta api uap dan seterusnya (Mubarak, 2018).

Babak kedua setelah mesin uap ditemukan adalah revolusi kedua melalui listrik. Listrik sebagai kata kunci $2 \mathrm{R}$ adalah penemuan spektakuler yang mengubah banyak hal dalam kehidupan. Masa ini terjadi pada rentang tahun 1860-1900 dimana mesin uap dipandang tidak cukup untuk kemajuan industri. Coal atau batu bara yang menjadi energi untuk membakar air menjadi mesin uap dan uap menjadi energi untuk menggerakkan mesin terbatas jumlahnya. Mesin yang digerakan oleh uap pun kompleks dan tidak sederhana sehingga untuk mempermudah proses mekanismenya ditemukanlah energi baru bernama listrik (electricity).

Revolusi industri ketiga ditandai dengan ditemukannya komputer. Komputer yang lahir dari alat untuk menghitung (compute) berevolusi menjadi alat yang multi talenta. Era ini lahir pada rentang tahun 1980 sampai 1990 dan berdampak terhadap kebijakan ekonomi, politik, pendidikan dan bahkan masyarakat secara umum. Diera ini pula mulai terjadi revolusi industri dimana kekuatan komputer menjadi salah satu kekuatan utama. Memindahan data manual kepada data virtual dan digital adalah hiruk pikuk di era ini. Surat manual diganti dengan e-mail, sistem informasi dari brosur dan banner menjadi www.com dan seterusnya. Era ini disebut era digital, dimana semua hal dihitung dan diatur dengan pola komputer. Jadi, komputer telah merevolusi manusia dari yang manual kepada yang digital. Pola ini telah mengubah unit produksi yang lama menjadi instan, yang jauh menjadi dekat dan dokumentatif, yang ribet menjadi sederhana dan mudah. Inilah era baru pada tahap ketiga yang menjadi dasar pada era keempat saat ini.

4IR ditandai dengan kemajuan hebat dari computer. Kemajuan computer yang asalnya hanya diterjemahkan sebagai alat informasi dan alat hitung berteknologi tinggi menjadi "exponential technologies." 4IR adalah revolusi yang mengintegrasikan efek parallel dari teknologi eksponen yang multi menjadi sebuah kekuatan baru dalam kehidupan. Eksponen kehidupan dimaksud adalah (1) Artificial Intellegent atau kecerdasan buatan, (2) biotechnologies dan (3) nanomaterial. Tiga eksponen ini adalah teknologi terbaru hasil pengembangan kekuatan komputer 
yang dienkripsi menjadi teknologi terbaru yang sangat rumit dan nano sangat kecil. Salah satu contohnya computer saat ini tidak butuh lagi monitor yang keras, besar dan benda padat. la bisa menggunakan teknologi hydrogen, di mana monitor bisa dibentuk di alam bebas berbasis hydrogen. Contoh lain dari realitas 4IR adalah dibuatnya organ manusia buatan (organism synsthetic) yang bisa dibuat oleh computer dengan mengambil sampel DNA dan diprint out oleh bioprinted. Contoh lainnya lagi tentang kecerdasan buatan yang computer lakukan bisa mendesain robot dengan kualitas manusia. Di pabrik-pabrik assembling, para robot ini cekatan merangkai produk teknologi dengan teliti, tepat dan tanpa cacat.

\section{Implementasi Kurikulum 2013 Revisi Sebagai Solusi Alternatif Pendidikan Di Indonesia Dalam Menghadapi Revolusi Industri 4.0}

Disrupsi teknologi, khususnya teknologi informasi telah mewarnai revolusi industri 4.0 sehingga mendorong perubahan kebutuhan dan perkembangan masyarakat dalam berbagai bidang kehidupan, termasuk pendidikan. Pendidikan yang hanya berorientasi pada pengembangan kemampuan intelektual otak kiri tidak dapat dipertahankan lagi. Hal ini merupakan salah satu pemicu perlunya dilakukan revisi terhadap kurikulum 2013 sebagai antisipasi perkembangan dan kebutuhan abad 21. Hal ini tentunya agar pendidikan dapat menyiapkan lulusan-lulusan berkualitas yang mampu bersaing, bersanding bahkan bertanding dalam era globalisasi yang penuh dengan berbagai permasalahan dan tantangan yang semakin rumit dan kompleks. Globalisasi telah merubah cara hidup manusia sebagai individu, sebagai warga masyarakat dan sebagai warga bangsa. Tidak seorangpun yang dapat menghindari dari arus globalisasi (Kunandar, 2010).

Untuk kepentingan tersebut, proses pendidikan harus lebih diorientasikan pada pengembangan kreativitas otak kanan, yang harus dipersiapkan melalui kurikulum yang realistis, dinamis dan fleksibel.

Kurikulum merupakan salah satu alat untuk mencapai tujuan pendidikan, sekaligus merupakan pedoman dalam pelaksanaan pembelajaran pada semua jenis dan jenjang pendidikan (Arifin, 2011).

Revisi Kurikulum 2013 merupakan perubahan kurikulum yang disesuaikan dengan penataan Standar Nasional Pendidikan (SNP), terutama Standar Kompetensi Lulusan (SKL), Standar Isi (SI), Standar Proses (SP) dan Standar Penilaian Pendidikan (SPP). Hasil revisi kurikulum ini semula akan diberi nama Kurikulum Nasional (Kurnas), tetapi akhirnya diberi nama Kurikulum 2013 
Revisi.Kurikulum 2013 Revisi merupakan wujud penyempurnaan kurikulum yang berbasis karakter sekaligus berbasis kompetensi dan diberlakukan secara berangsur-angsur tahun ajaran 2017/2018 yakni pada jenjang pendidikan dasar dan menengah. Dengan demikian secara bertahap Indonesia dapat menyiapkan generasi emas yang berkualitas sehingga mampu menanggalkan sekaligus meninggalkan status negara berkembang menuju negara maju.Penyempurnaan kurikulum perlu dilakukan secara terus menerus dan berkesinambungan (continius quality improvement) untuk memperoleh hasil yang optimal, terutama berkaitan dengan penerapan serta penjabaran Standar Isi (SI) dan Standar Kompetensi Lulusan (SKL).

Dalam implementasinya, kurikulum 2013 Revisi menuntut guru untuk mengembangkan pembelajaran dengan mengintegrasikan empat hal penting, yaitu Penguatan Pendidikan Karakter (PPK), Literasi, Keterampilan Abad ke-21 (4C) dan Higher Order Thingking Skill (HOTS) yang memerlukan kreativitas guru dalam meramunya (Mulyasa, 2018).

Gerakan Penguatan Pendidikan Karakter (PPK) perlu diintegrasikan dalam pembelajaran terutama untuk memperdalam, memperluas dan sekaligus menyelaraskan berbagai program dan kegiatan pendidikan karakter yang sudah dilaksanakan sampai sekarang. Integrasi PPK dalam pembelajaran terutama ditekankan pada pembentukan lima karakter, yaitu religius, nasionalis, mandiri, gotong royong dan integritas.

Integrasi literasi dalam konteks Gerakan Literasi Sekolah (GLS) ditunjukkan untuk meningkatkan kemampuan warga sekolah khususnya peserta didik dalam mengakses, memahami, dan menggunakan sesuatu secara cerdas melalui berbagai aktivitas antara lain membaca, menulis dan berbicara. Literasi lebih dari sekedar membaca dan menulis, namun mencakup keterampilan berpikir menggunakan sumber-sumber belajar dan sumber-sumber pengetahuan dalam bentuk cetak, visual, digital dan auditori. Literasi dapat dijabarkan melalui literasi dasar (basic literacy), literasi perpustakaan (library literacy), literasi media (media literacy), literasi teknologi (technology literacy) dan literasi visual (visual literacy).

Literasi dasar yakni kemampuan mendengarkan, berbicara, membaca, menulis dan menghitung, berkaitan dengan kemampuan analisis untuk memperhitungkan (calculating), mempersepsikan informasi (perceiving), 
mengkomunikasikan, serta menggambarkan informasi (drawing) berdasarkan pemahaman dan pengambilan kesimpulan pribadi.

Literasi perpustakaan (library literacy) adalah kemampuan pemahaman cara membedakan bacaan fiksi dan non fiksi, memanfaatkan koleksi, referensi dan periodical, memahami Dewey Decimal System sebagai klasifikasi pengetahuan yang memudahkan dalam menggunakan perpustakaan, memahami penggunaan catalog dan pengindekasan hingga memiliki pengetahuan dalam memahami informasi ketika sedang menyelesaikan sebuah tulisan, penelitian, pekerjaan atau mengatasi masalah.

Literasi media (media literacy) adalah kemampuan untuk mengetahui berbagai bentuk media yang berbeda, seperti media cetak, media elektronik (radio, televisi), media digital (internet), dan memahami tujuan penggunaannya. Literasi teknologi (technology literacy) adalah kemampuan memahami kelengkapan teknologi seperti piranti keras (hardware), peranti lunak (software) serta etika dan etiket dalam memanfaatkan teknologi, kemampuan dalam memahami teknologi untuk mencetak, mempresetasikan dan mengakses internet, kemampuan dalam menggunakan komputer yang didalamnya mencakup menghidupkan dan mematikan komputer, menyimpan dan mengelola data serta mengoperasikan program perangkat lunak dan pemahaman yang baik dalam mengelola informasi yang dibutuhkan masyarakat.

Literasi visual (visual literacy) adalah kemampuan memanfaatkan materi visual dan audiovisual secara kritis dan bermartabat serta kemampuan menafsirkan materi visual baik dalam bentuk cetak, auditori maupun digital atau perpaduannya.

Tabel. Contoh Kegiatan Literasi Sekolah

\begin{tabular}{|c|c|c|c|c|}
\hline \multirow[t]{2}{*}{ No } & \multirow[t]{2}{*}{ Komponen } & \multicolumn{3}{|c|}{ Contoh Kegiatan } \\
\hline & & $\begin{array}{c}\text { Tahap } \\
\text { Pembiasaan }\end{array}$ & Tahap Pengembangan & $\begin{array}{c}\text { Tahap } \\
\text { Pembelajaran }\end{array}$ \\
\hline 1. & Literasi Dasar & $\begin{array}{l}\text { Membaca } 15 \\
\text { menit sebelum } \\
\text { kegiatan belajar } \\
\text { setiap hari }\end{array}$ & Mendiskusikan bacaan & $\begin{array}{l}\text { Menuliskan analisis } \\
\text { terhadap bacaan }\end{array}$ \\
\hline 2. & $\begin{array}{l}\text { Literasi } \\
\text { Perpustakaan }\end{array}$ & $\begin{array}{l}\text { Mencari bahan } \\
\text { pustaka yang } \\
\text { diminati untuk } \\
\text { kegiatan } \\
\text { membaca } 15 \\
\text { menit }\end{array}$ & $\begin{array}{l}\text { Menggunakan } \\
\text { perpustakaan sebagai } \\
\text { sumber informasi dalam } \\
\text { diskusi tentang bacaan }\end{array}$ & $\begin{array}{l}\text { Mencantumkan } \\
\text { daftar pustaka dalam } \\
\text { laporan tugas/praktik } \\
\text { setiap mata pelajaran }\end{array}$ \\
\hline 3. & Literasi Media & $\begin{array}{l}\text { Membaca berita } \\
\text { dari media cetak } \\
\text { dalam kegiatan }\end{array}$ & $\begin{array}{l}\text { Mendiskusikan berita } \\
\text { dari media }\end{array}$ & $\begin{array}{l}\text { Membuat komunikasi } \\
\text { pembelajaran untuk } \\
\text { diskusi dan berbagi }\end{array}$ \\
\hline
\end{tabular}




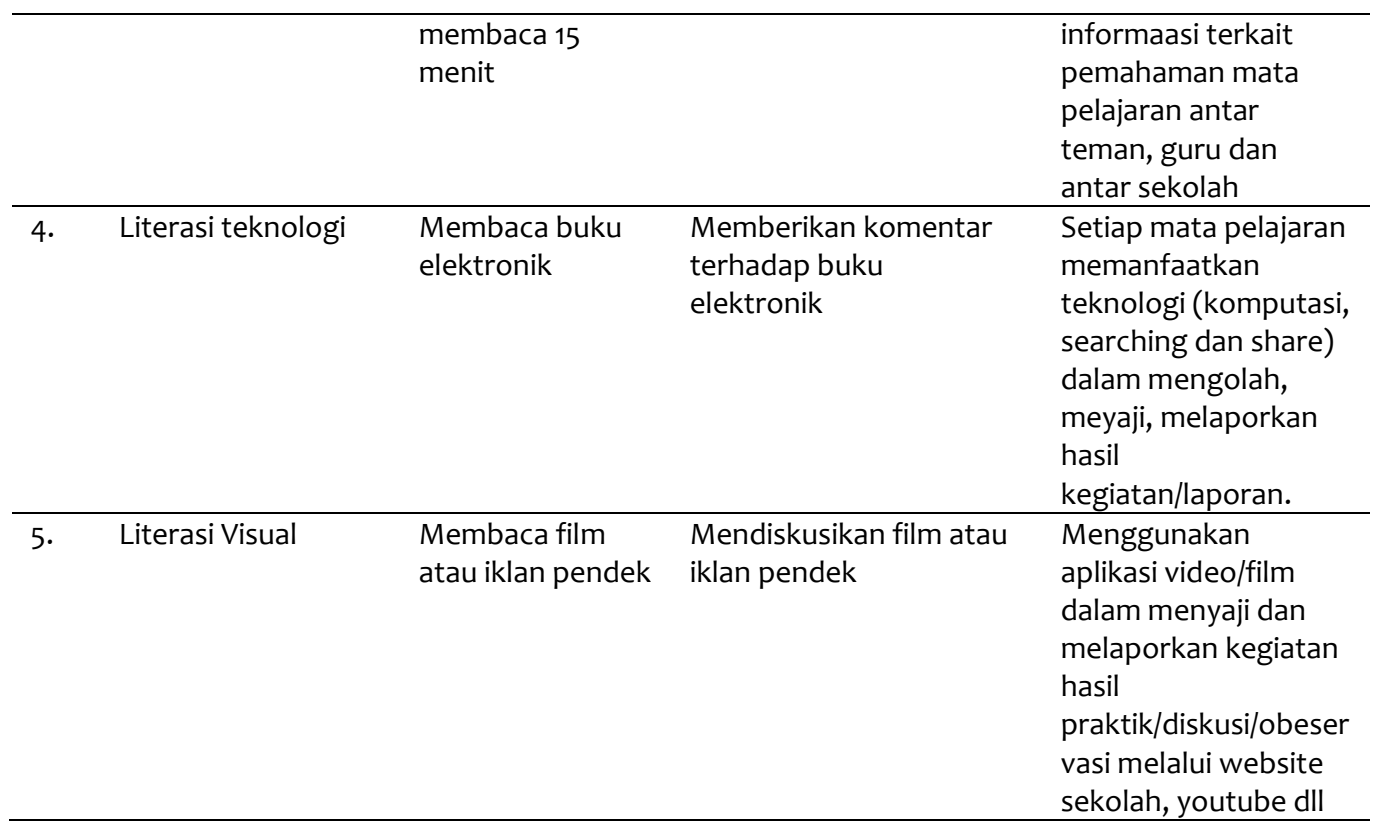

Integrasi keterampilan abad ke-21 yang mencakup 4 C (Communication, Collaboration, Critical Thingking and Problem Solving, dan Creativity and Innovation), merupakan bentuk antisipasi kurikulum terhadap perkembangan teknologi dan penerapannya dimasyarakat. Inilah sesungguhnya yang ingin diwujudkan dalam Kurikulum 2013 Revisi, bukan sekedar transfer ilmu pengetahuan atau materi, tetapi pembentukan kompetensi abad ke 21. Integrasi keterampilan abad ke-21 dalam pembelajaran di sekolah sangat penting, karena kemampuan $4 \mathrm{C}$ merupakan jenis softskill yang pada implementasi keseharian jauh lebih bermanfaat daripada sekedar penguatan hardskill. Pembelajaran yang menekankan pada keterampilan abad ke-21 juga menekankan tentang pentingnya pengembangan otak kanan peserta didik. Oleh karena itu, guru-guru dituntut untuk mengubah mindset dari pengembangan otak kiri ke pengembangan otak kanan yang berbasis kreativitas.

Integrasi Higher Order Thinking Skill (HOTS) yang mencakup kemampuan berpikir kritis, logis, reflektif, metakognitif dan berpikir kreatif merupakan kemampuan berpikir tingkat tinggi yang harus dimiliki peserta didik. Oleh karena itu, Kurikulum 2013 revisi juga menuntut materi pembelajarannya sampai metakognitif yang mensyaratkan peserta didik mampu untuk memprediksi, mendesain, dan memperkirakan. Sejalan dengan itu, ranah HOTS yaitu analisis yang merupakan kemampuan berpikir dalam menspesifikasi elemen-elemen dari sebuah konteks tertentu, evaluasi merupakan kemampuan berpikir dalam mengambil keputusan 
berdasarkan fakta/informasi dan mengkreasi merupakan kemampuan berpikir dalam membangun dan mengembangkan peserta didik, agar mereka dapat menghadapi dan menikmati kehidupannya kelak di masyakarat yang senantias disentuh dan bersentuhan dengan teknologi.

Integrasi penguatan pendidikan karakter (PPK), Literasi, Keterampilan Abad 21 (4C) dan Higher Oreder Thinking Skill (HOTS) dalam pembelajaran dapat dilakukan sebagai berikut:

1. Pemanduan kegiatan kelas, luar kelas di sekolah dan luar sekolah (masyarakat/komunitas)

2. Pemanduan kegiatan intrakurikuler, kokurikuler dan ekstrakurikuler

3. Pelibatan secara serempak warga sekolah, keluarga dan masyarakat sebagi sumber belajar

Pendalaman dan perluasan pembelajaran dapat berupa kegiatan-kegiatan sebagai berikut:

1. Penambahan dan pengintensifan kegiatan-kegiatan yang berorientasi pada pengembangan karakter peserta didik

2. Penambahan dan penajaman kegiatan belajar peserta didik, serta pengaturan ulang waktu belajar peserta didik di sekolah dan di luar sekolah

3. Penyelarasan dapat berupa penyesuaian tugas pokok guru, Manajemen Berbasis Sekolah (MBS) dan fungsi komite dengan kebutuhan gerakan PPK.

Perubahan kurikulum 2013 Revisi dilakukan berdasarkan penataan Standar Nasional Pendidikan (SNP), yang berangkat dari kompetensi-kompetensi sebagai hasil analisis dari berbagai kebutuhan masyarakat, baik kebutuhan untuk hidup (bekerja) maupun untuk mengembangkan diri sesuai dengan pendidikan seumur hidup. Oleh karena itu, pengembangan kurikulum 2013 revisi memperhatikan kebutuhan dan tren-tren yang sedang berkembang di masyarakat.Pemahaman dan penerapan kurikulum 2013 revisi menuntut guru, kepala sekolah dan pengawas untuk senantiasa bekerja sama dan berkolaborasi dengan memperhatikan komponen utama sebagai berikut :

1. Standar Kompetensi Lulusan (SKL) harus dijabarkan dan dikembangkan secara spesifik ke dalam Kompetensi Inti (KI) dan Kompetensi Dasar (KD). 
2. Pembelajaran perlu direncanakan dan dikembangkan berdasarkan standar proses secara matang untuk menentukan bahwa kegiatan pembelajaran sudah dapat dilaksanakan secara efektif dan menyenangkan

3. Pembelajaran yang dikembangkan harus menggambarkan secara jelas standar proses, standar isi, dan standar penilaian

4. Penilaian perlu memperhatikan keseimbangan antar berbagai aspek yang dinilai ( $\mathrm{KI}-1, \mathrm{KI}-2, \mathrm{KI}-3$ dan $\mathrm{KI}-4$ ) dengan mengacu pada Permendikbud Tahun 2016 No.23 Tentang Standar Penilaian.

Dalam kaitannya dengan Standar Nasional Pendidikan, terdapat empat dari delapan standar yang dilakukan perubahan dan penataan dalam rangka implementasi Kurikulum 2013 Revisi, yang perlu diperhatikan dan dikembangkan dalam implementasi kurikulum 2013 di sekolah. Keempat standar nasional pendidikan yang direvisi tersebut adalah standar kompetensi lulusan, standar isi, standar proses, dan standar penilaian pendidikan. Penataan empat standar nasional pendidikan disesuaikan dengan karaktersitik sekolah, daerah, dan karaktersitik setiap bidang studi terutama dalam kaitannya dengan pekerjaan yang ada di masyarakat dan tuntunan kehidupan nyata. Sebagai contoh: standar kompetensi, standar isi, standar proses, dan standar penilaian pendidikan bahasa perlu lebih ditekankan pada kemampuan berbicara, agar para peserta didik mampu berkomunikasi secara aktif dan menggunakan bahasa sebagai alat untuk memecahkan berbagai permasalahan dalam kehidupan sehari-hari.

Implementasi kurikulum 2013 revisi menginsyarakatkan dan menuntut guru untuk mengintegrasikan muatan-muatan karakter dalam setiap pembelajaran, sesuai dengan visi, serta misi sekolah dan daerah masing-masing. Inilah salah satu kelebihan dari Kurikulum 2013 Revisi yang diharapkan dapat menghasilkan lulusan yang produktif, kreatif, inovatif dan berkarakter. Dalam pada itu kurikulum ini juga diharapkan mampu memecahkan berbagai masalah kesenjangan pendidikan dengan dunia kerja, dan dalam jangka panjang diharapkan dapat menyiapkan sumber daya manusia berkualitas sebagai generasi emas di tahun 2045.

Penekanan terhadap suatu karakter dan kompetensi akan memberi warna terhadap sekolah yang satu akan berbeda dengan sekolah yang berada di daerah lain. Meskipun demikian, persamaan setiap sekolah itu tetap muncul dan diikat oleh Standar Nasional Pendidikan (SNP) yang dikembangkan dan digariskan oleh Badan Standar Nasional Pendidikan (BSNP). 
Hakikat Kurikulum 2013 Revisi adalah kebebasan guru dalam mengembangkan kurikulum sesuai dengan perubahan terhadap empat standar yakni Standar Kompetensi Lulusan (SKL), standar isi, standar proses dan standar penilaian pendidikan. Jika sebelumnya guru diberi kebebasan dalam mengembangkan dan menjabarkan kurikulum di sekolah maka dalam kurikulum 2013 revisi, guru harus memperhatikan perubahan pada empat standar nasional pendidikan dan mengkaji berbagai pedoman seperti pedoman guru dan pedoman peserta didik. Penilaian kurikulum 2013 Revisi lebih ditekankan pada penilaian yang utuh dan menyeluruh atau penilaian yang asli (authentic assesment) yang pelaporannya dideskripsikan. Dalam hal ini, apa-apa yang dijadikan bahan penilaian berangkat dari kegiatan kontekstual yang terjadi dan berlangsung dalam pembelajaran secara utuh, menyeluruh dan berkesinambungan. Di samping itu, penilaian juga dilengkapi dengan portofolio, untuk menganalisis kemajuan dan perkembangan tugas-tugas pembelajaran yang dilakukan oleh peserta didik.

Dalam implementasi Kurikulum 2013 Revisi, guru, kepala sekolah dan pengawas dituntut untuk senantiasa belajar agar dapat mengembangkan dan memperkaya diri melalui informasi baru yang berkaitan dengan pembelajaran dan peningkatan kualitas pendidikan pada umumnya. Revisi kurikulum 2013 dilakukan sesuai dengan perubahan dan penataan Standar Nasional Pendidikan (SNP) terutama berkaitan dengan empat standar, yakni standar kompetensi lulusan, standar isi, standar proses dan standar penilaian pendidikan. Perubahan tersebut dilakukan berdasarkan hasil analisis dari berbagai kebutuhan peserta didik, baik kebutuhan untuk hidup (bekerja) maupun untuk mengembangkan diri sesuai pendidikan seumur hidup. Oleh karena itu, pengembangan kurikulum dilakukan dengan menempuh dan mencakup dua langkah berikut. Pertama, merumuskan visi dan misi pendidikan nasional berdasarkan Pancasila dan UUD 1945. Kedua, menjabarkan kompetensi-kompetensi inti berdasarkan visi dan misi. Kompetensikompetensi inti dirumuskan untuk mengakomodasi kebutuhan berbagai pihak dalam berbagai dimensi masyarakat, baik kebutuhan sekarang maupun masa depan tanpa melupakan kebutuhan masa lalu yang tidak terealisasikan.

Kurikulum dan pembelajaran yang baik adalah yang mampu mengembangkan potensi peserta didik secara optimal pada zamannya. Oleh karena itu, salah satu perubahan yang menjadi karakteristik kurikulum 2013 revisi terletak pada standar proses bahwa pembelajaran harus mampu mengembangkan 
kemampuan berpikir tingkat tinggi (Higher Order Thinking Skill/HOTS). Melalui pembelajaran kreatif yang melatih kemampuan berpikir tingkat tinggi diharapkan.

\section{Kesimpulan}

Berdasarkan uraian pada pembahasan, maka kesimpulan pada tulisan ini yakni sebagai berikut:

Disrupsi teknologi, khususnya teknologi informasi telah mewarnai revolusi industri 4.0 sehingga mendorong perubahan kebutuhan dan perkembangan masyarakat dalam berbagai bidang kehidupan, termasuk pendidikan. Pendidikan yang hanya berorientasi pada pengembangan kemampuan intelektual otak kiri tidak dapat dipertahankan lagi. Hal ini merupakan salah satu pemicu perlunya dilakukan revisi terhadap kurikulum 2013 sebagai antisipasi perkembangan dan kebutuhan abad 21. Untuk kepentingan tersebut, proses pendidikan harus lebih diorientasikan pada pengembangan kreativitas otak kanan, yang harus dipersiapkan melalui kurikulum yang realistis, dinamis dan fleksibel.

Revisi Kurikulum 2013 merupakan perubahan kurikulum yang disesuaikan dengan penataan Standar Nasional Pendidikan (SNP), terutama Standar Kompetensi Lulusan (SKL), Standar Isi (SI), Standar Proses (SP) dan Standar Penilaian Pendidikan (SPP). Dalam implementasinya,kurikulum 2013 Revisi menuntut guru untuk mengembangkan pembelajaran dengan mengintegrasikan empat hal penting, yaitu Penguatan Pendidikan Karakter (PPK), Literasi, Keterampilan Abad ke-21 (4C) dan Higher Order Thingking Skill (HOTS) yang memerlukan kreativitas guru dalam meramunya. Implementasi kurikulum 2013 revisi menginsyarakatkan dan menuntut guru untuk mengintegrasikan muatan-muatan karakter dalam setiap pembelajaran, sesuai dengan visi, serta misi sekolah dan daerah masing-masing. Inilah salah satu kelebihan dari Kurikulum 2013 Revisi yang diharapkan dapat menghasilkan lulusan yang produktif, kreatif, inovatif dan berkarakter. Dalam pada itu kurikulum ini juga diharapkan mampu memecahkan berbagai masalah kesenjangan pendidikan dengan dunia kerja, dan dalam jangka panjang diharapkan dapat menyiapkan sumber daya manusia berkualitas sebagai generasi emas di tahun 2045 . 


\section{Referensi.}

Arifin, Z. (2011). Konsep dan Model Pengembangan Kurikulum. Bandung: Remaja Rosdakarya.

Engkoswara, \& Komariah, A. (2011). Administrasi Pendidikan. Bandung: Alfabeta.

Kunandar. (2010). Guru Profesional. Jakarta: PT.Rajagrafindo Persada.

Mubarak, Z. (2018). Pendidikan Di Era Revolusi Industri 4.0 Dan Problematika Pendidikan Tinggi. Yogyakarta: Ganding Pustaka.

Mulyasa, E. (2013). Implementasi Kurikulum 2013 Revisi Dalam Era Revolusi Industri 4.0. Jakarta: Bumi Aksara.

Mulyasa, E. (2018). Pengembangan dan Implementasi Kurikulum 2013: Perubahan dan Pengembangan Kurikulum 2013 Merupakan Persoalan Penting dan Genting.

Sukmadinata, \& Syaodih, N. (2017). Pengembangan Kurikulum. Bandung: PT Remaja Rosdakarya.

Tim Redaksi Sinar Grafika. (2007). Undang-Undang Sistem Pendidikan Nasional Nomor 20 Tahun 2003. Jakarta: Sinar Grafika.

Trianto. (2007). Model-Model Pembelajaran Inovatif Berorientasi Konstruktivistik. Jakarta: Prestasi Pustaka Publisher. 